\title{
Isolation and Identification of a Rumen Lactobacillus Bacteria and Its Degradation Potential of Gossypol in Cottonseed Meal during Solid-State Fermentation
}

\author{
Wei-Kang Wang (D), Wen-Juan Li, Qi-Chao Wu, Yan-Lu Wang, Sheng-Li Li and Hong-Jian Yang *(D) \\ State Key Laboratory of Animal Nutrition, College of Animal Science and Technology, China Agricultural \\ University, Beijing 100193, China; 18292092306@163.com (W.-K.W.); liwjuan1226@163.com (W.-J.L.); \\ wuqichao@cau.edu.cn (Q.-C.W.); wang_yanlu@cau.edu.cn (Y.-L.W.); lisheng0677@163.com (S.-L.L.) \\ * Correspondence: yang_hongjian@sina.com
}

\section{check for} updates

Citation: Wang, W.-K.; Li, W.-J.; Wu, Q.-C.; Wang, Y.-L.; Li, S.-L.; Yang, H.-J. Isolation and Identification of a Rumen Lactobacillus Bacteria and Its Degradation Potential of Gossypol in Cottonseed Meal during Solid-State Fermentation. Microorganisms 2021, 9 , 2200. https://doi.org/10.3390/ microorganisms 9112200

Academic Editors: Yimin Cai, Zaenal Bachruddin and Jianguo Zhang

Received: 13 September 2021 Accepted: 19 October 2021 Published: 21 October 2021

Publisher's Note: MDPI stays neutral with regard to jurisdictional claims in published maps and institutional affiliations.

Copyright: (c) 2021 by the authors. Licensee MDPI, Basel, Switzerland. This article is an open access article distributed under the terms and conditions of the Creative Commons Attribution (CC BY) license (https:/ / creativecommons.org/licenses/by/ $4.0 /)$.
Abstract: Cottonseed meal (CSM) is an important protein feed source for dairy cows. Its inclusion in ruminant diets is limited due to the presence of the highly toxic gossypol though rumen microorganisms are believed to be capable of gossypol degrading and transforming. The objective of the present study was to isolate the gossypol-degrading bacteria from the rumen contents and to assess its potential for gossypol degradation in vitro. A strain named Lactobacillus agilis WWK129 was anaerobically isolated from dairy cows after mixed rumen microorganisms were grown on a substrate with gossypol as the sole carbon source. Furthermore, the strain was applied at $5 \%$ inoculum concentration in vitro to continuously ferment CSM at $39{ }^{\circ} \mathrm{C}$ for five days, and it presented gossypol degradability as high as $83 \%$. Meanwhile, the CSM contents of crude protein, essential amino acids increased significantly along with the increase of lactic acid yield $(p<0.01)$. Compared with the original CSM, the fermented CSM contents of neutral detergent fiber and acid detergent fiber was remarkably decreased after the anaerobic fermentation $(p<0.01)$. In brief, the Lactobacillus strain isolated from the rumen is not only of great importance for gossypol biodegradation of CSM, but it could also be used to further explore the role of rumen microorganisms in gossypol degradation by the ruminants.

Keywords: gossypol; rumen; solid-state fermentation; cottonseed meal

\section{Introduction}

Gossypol $\left(\mathrm{C}_{30} \mathrm{H}_{30} \mathrm{O}_{8}\right)$, a polyphenolic compound (Figure 1) produced by the cotton plant (Gossypium sp.), is one of the anti-nutritional factors to limit the application of cotton by-products in animal production [1,2]. For a long time, excessive intake of gossypol has been found to cause growth depression [3], reproductive performances decline, anemia, as well as other internal organ abnormalities in animals [4,5]. Adult ruminants were believed more tolerant to gossypol than monogastric animals as well as young ruminants [6]. Such tolerance was believed to be associated with the characteristics of gossypol binding to soluble proteins and gossypol partially degrading ability of rumen microbes $[7,8]$.

As for cottonseed meal (CSM), an important protein feedstuff, three methods have been commonly used in animal feed processing for many years to reduce gossypol's toxicity, including i) mechanical processing [9], ii) chemical treatment [10,11], and iii) microbial fermentation [12]. Among these methods, microbial fermentation was considered the most promising method for gossypol detoxification as well as a nutritional improvement compared with the other methods with subsiding effects, especially for CSM [13,14]. Numerous fungi were reported to play an important role in CSM fermentation for gossypol degradation, including Candida tropicalis, Saccharomyces cerevisiae, Aspergillus oryzae, Aspergillus terreus, and Aspergillus niger [15,16]. Although these fungi were found capable of gossypol degradation, some fungi metabolites were toxic to animals, e.g., citrinin secreted 
by Aspergillus species [17]. Thus the safety of fermentation products by fungi generally used as animal feeds must be assessed. To overcome the above constraints of extrinsic environmental microorganisms, the authors in the present study hypothesized that there should be some endogenous microbes capable of gossypol degradation in the rumen. Therefore, the objectives of the present study attempted to isolate potential microorganism strain with gossypol degradation ability from rumen contents, and CSM was chosen as a mode gossypol containing feed to investigate if the strain could rebuild the nutritional nature of CSM.<smiles>Cc1cc2c(C(C)C)c(O)c(O)c(C=O)c2c(O)c1-c1c(C)cc2c(C(C)C)c(O)c(O)c(C=O)c2c1O</smiles>

Figure 1. The structure of free gossypol $\left(\mathrm{C}_{30} \mathrm{H}_{30} \mathrm{O}_{8}\right)$.

\section{Materials and Methods}

\subsection{Isolation of Gossypol Degradation Bacteria}

Rumen liquid was collected from the rumen central of three mature lactating Holstein cows with ruminal cannulas (average body weight: $502 \pm 25 \mathrm{~kg}, 151$ days in milk and $36 \mathrm{~kg} / \mathrm{d}$ of milk yield at the beginning of the study), and filtered through four layers of cheesecloth. Cows were individually housed in three stalls with good ventilation and were fed $25 \mathrm{~kg}$ of dry matter (DM) $(110 \mathrm{~g} / \mathrm{kg}$ of imported Alfalfa, $490 \mathrm{~g} / \mathrm{kg}$ of silage maize, $140 \mathrm{~g} / \mathrm{kg}$ of pressed corn, and $260 \mathrm{~g} / \mathrm{kg}$ of mixture) per animal per day, and free access to drinking water. The cows were fed at 09:00 am and 15:00 pm, and milked three times daily. The filtrated rumen fluids from the three animals were mixed in equal proportion. Approximately $1 \mathrm{~mL}$ of the rumen liquid was diluted with saline solution to make $10^{-1}$ and $10^{-2}$ dilutions of rumen liquid, $1 \mathrm{~mL}$ of different concentrations of

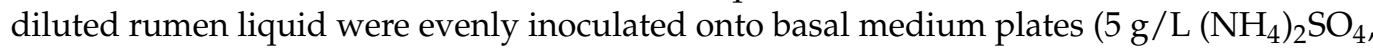
$1 \mathrm{~g} / \mathrm{L} \mathrm{KH}_{2} \mathrm{PO}_{4}, 1 \mathrm{~g} / \mathrm{L} \mathrm{NaCl}, 0.5 \mathrm{~g} / \mathrm{L} \mathrm{MgSO}_{4} .7 \mathrm{H}_{2} \mathrm{O}, 0.1 \mathrm{~g} / \mathrm{L} \mathrm{CaCl}_{2}, 0.2 \mathrm{~g} / \mathrm{L}$ yeast extract, $15 \mathrm{~g} / \mathrm{L}$ agar) [16] containing $1 \mathrm{~g} / \mathrm{L}$ gossypol as the sole carbon source and then cultured at $39{ }^{\circ} \mathrm{C}$ for three days using AY6907 anaerobic jar (GeneScience, Wilmington, USA) which reached anaerobic condition by the inlet of $\mathrm{CO}_{2}$ to remove $\mathrm{O}_{2}$ (Figure 2). The isolated strain was identified and inoculated on DeMan-Rogosa-Sharpe (MRS) medium $(10 \mathrm{~g} / \mathrm{L}$ peptone, $20 \mathrm{~g} / \mathrm{L}$ glucose, $5 \mathrm{~g} / \mathrm{L}$ yeast extract, $4 \mathrm{~g} / \mathrm{L} \mathrm{K}_{2} \mathrm{HPO}_{4}, 5 \mathrm{~g} / \mathrm{L} \mathrm{CH}_{3} \mathrm{COONa}, 10 \mathrm{~g} / \mathrm{L}$ beef extract, $2 \mathrm{~g} / \mathrm{L} \mathrm{C}_{6} \mathrm{H}_{5} \mathrm{O}_{7}\left(\mathrm{NH}_{4}\right)_{3}, 1 \mathrm{~mL} / \mathrm{L}$ Tween-80, $0.56 \mathrm{~g} / \mathrm{L} \mathrm{MgSO}_{4} .7 \mathrm{H}_{2} \mathrm{O}, 0.14 \mathrm{~g} / \mathrm{L} \mathrm{MnSO} \mathrm{M}_{4} . \mathrm{H}_{2} \mathrm{O}$, $15 \mathrm{~g} / \mathrm{L}$ agar) [18] and incubated for three days at $39^{\circ} \mathrm{C}$ to obtain pure cultures. The isolated strain was maintained at $4{ }^{\circ} \mathrm{C}$ on MRS medium. 


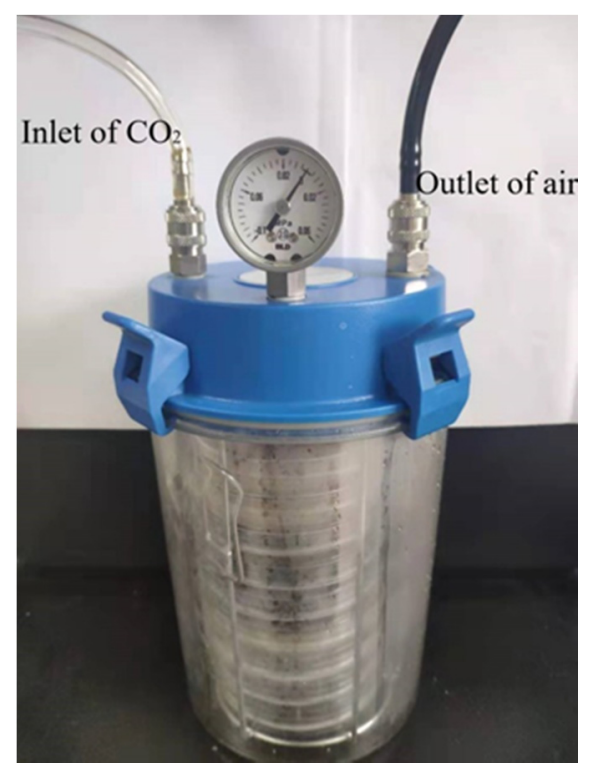

Figure 2. Instruction of anaerobic jar.

\subsection{Morphological Characteristics of the Strain}

The isolated strain was cultured in a liquid MRS medium for $24 \mathrm{~h}$ at $39{ }^{\circ} \mathrm{C}$ under anaerobic condition. Then the thallus was harvested and prefixed with a $2.5 \%$ glutaraldehyde solution overnight at $4{ }^{\circ} \mathrm{C}$. After it was prefixed, the thallus was washed with $0.1 \mathrm{M}$ sodium phosphate buffer solution ( $\mathrm{pH} 7.0$ ) three times and serially dehydrated with $50 \%$, $70 \%, 80 \%, 90 \%$, and $100 \%$ ethanol, respectively. Then, thallus was dried at the critical point. For scanning electron microscope (SEM), a thin film of thallus was sputter-coated with a thick gold film and observed with a HITACHI UHR FE-SEM SU8020 (Hitachi, Tokyo, Japan) SEM. For transmission electron microscope (TEM), thallus was treated with osmium tetroxide solution for $30 \mathrm{~min}$, and washed in phosphate buffer, dehydrated in ethanol gradients as described above, embedded in Epon-Araldite resin for making the blocks of the cells pellet. Ultra-thin sections of the thallus were stained in uranyl acetate and lead citrated, air-dried, and observed with a JEOL JEM-1200EX (Jeol, Tokyo, Japan) TEM [19].

\subsection{DNA Extraction and Bacteria Identification}

After the harvest of thallus as described in Section 2.2, the extraction of DNA was carried out by using the QIAamp ${ }^{\circledR}$ DNA stool mini kit (Qiagen Ltd., Crawley, West Sussex, UK) following the manufacturer's instructions. The concentration of total DNA was estimated using a Nanodrop 2000 (Thermo Scientific, Wilmington, USA) and purified DNA samples were stored at $-80^{\circ} \mathrm{C}$. The genomic DNA was amplified by polymerase chain reaction (PCR) for use as a template. The primers were 27F: $5^{\prime}$-AGAGTTTGATCCTGGCTCAG-3' and 1492R: $5^{\prime}$-ACGGTTACCTTGTTACGACTT-3' [20], and the PCR reaction was conducted using the following conditions: $2 \mathrm{~min}$ at $98^{\circ} \mathrm{C}$, followed by 35 cycles of $10 \mathrm{~s}$ at $98^{\circ} \mathrm{C}, 10 \mathrm{~s}$ at $56^{\circ} \mathrm{C}$, and $15 \mathrm{~s}$ at $72{ }^{\circ} \mathrm{C}$, and a final extension of $5 \mathrm{~min}$ at $72{ }^{\circ} \mathrm{C}$.

The isolated strain $16 \mathrm{~S}$ rDNA gene was sequenced by Beijing TSINGKE, China. The product of $16 \mathrm{~S}$ rDNA genes of the isolated strain in the present study was compared against National Center for Biotechnology Information database (NCBI) reported sequences with the Basic Local Alignment Search Tool (BLAST) hosted at the website of NCBI. A phylogenetic tree was then drawn using the Neighbor-joining method [21]. Phylogenetic and molecular evolutionary analysis were conducted at 1000 bootstrap value using Molecular Evolutionary Genetics Analysis (MEGA) version 5.0 software (Center of Evolutionary Functional Genomics, Biodesign Institute, Arizona State University, Tempe, AZ, USA) [22]. 


\subsection{Growth Study of Isolated Bacteria in Different Carbon Source}

Growth experiments were conducted with different carbon sources. After the isolated strain was anaerobically cultured in MRS medium for $24 \mathrm{~h}$ as described in Section 2.2, $1 \mathrm{~mL}$ cultures were inoculated onto $500 \mathrm{~mL}$ liquid MRS medium which used glucose or gossypol $(1 \mathrm{~g} / \mathrm{L})$ as carbon resource, respectively. Then, the inoculated MRS mediums were mixed well and divided $2 \mathrm{~mL}$ into each tube. All of these tubes were anaerobically incubated at $39^{\circ} \mathrm{C}$, bacteria growth of 3 tubes was determined by optical density at $600 \mathrm{~nm}$ every $1 \mathrm{~h}$ using a spectrophotometer.

\subsection{Solid-State Fermentation and Chemical Analysis}

A representative CSM sample that contained $500 \mathrm{mg} / \mathrm{g}$ gossypol was dried at $65{ }^{\circ} \mathrm{C}$ for $24 \mathrm{~h}$ in a forced-air oven and ground to pass through a $0.25-\mathrm{mm}$ screen. The nutritive composition of CSM sample included $164 \mathrm{~g} / \mathrm{kg}$ of neutral detergent fiber (NDF), $115 \mathrm{~g} / \mathrm{kg}$ of acid detergent fiber (ADF) and $500 \mathrm{~g} / \mathrm{kg}$ of crude protein (CP) in DM. Then the CSM sample was autoclave sterilized at $121^{\circ} \mathrm{C}$ for $25 \mathrm{~min}$. The isolated strain was cultured in liquid MRS medium for $24 \mathrm{~h}$ at $39^{\circ} \mathrm{C}$ under anaerobic condition, and $1.5 \mathrm{~mL}$ cultured medium was diluted to $15 \mathrm{~mL}$ by liquid MRS medium. For each fermentation period, a $15 \mathrm{~g}$ CSM sample was inoculated with $15 \mathrm{~mL}$ of the diluted cultured medium in each $10 \mathrm{~cm}$ culture dish, resulting in 5\% inoculum level and 50\% moisture in dry matter (DM). All of these culture dishes (5 incubation time $\times 3$ replicates) were put in a anaerobic jar, purged with $\mathrm{CO}_{2}$ to obtain anaerobic condition, and anaerobically incubated at $39^{\circ} \mathrm{C}$ for $1,2,3,4$, and 5 days, respectively. Meanwhile, to prevent the confusion of the effect of medium contents on fermentation results, a $15 \mathrm{~g}$ CSM sample was inoculated with $15 \mathrm{~mL}$ liquid MRS medium without isolated strain in three replicates and incubated at the same conditions as above for five days.

After incubation was completed, CSM samples were dried in an oven at $65^{\circ} \mathrm{C}$ for $48 \mathrm{~h}$ for later analysis. Crude proteinwas determined according to AOAC methods [23], amino acids were assayed using a Hitachi L-8800 instrument (Hitachi, Tokyo, Japan). Neutral detergent fiber and acid detergent fiber were determined following the method of Van Soest et al. [24]. Lactic acid was determined by High Performance Liquid Chromatography (HPLC) according to the methods of Cira et al. [25]. Gossypol content was determined as the methods of Wang et al. [26]: $1.5 \mathrm{~g}$ sample in $15 \mathrm{~mL}$ acetone was ultrasound $30 \mathrm{~min}$ at $40{ }^{\circ} \mathrm{C}$, centrifuged and collected the supernatant, repeat the above processes three times, the extraction was combined and filtrated with $0.45 \mu \mathrm{m}$ microporous, rotary evaporated, dissolved by acetonitrile $-0.2 \%$ phosphoric acid solution and fixed capacity to $2.5 \mathrm{~mL}$. The content of gossypol was quantified by HPLC with a Wufeng analytical instrument (Wufeng Co., Ltd., Shanghai, China). The analytical column was a symmetry reversed-phase C18 column $(250 \times 4.6 \mathrm{~mm}, 5 \mu \mathrm{m}, \mathrm{pH} 2-8$, Waters, Milford, MA, USA). The mobile phase was $85: 15(v / v)$ acetonitrile $-0.2 \%$ phosphoric acid solution at a flow rate of $1 \mathrm{~mL} / \mathrm{min}$. Injections were $20 \mu \mathrm{L}$, and the gossypol was detected at $235 \mathrm{~nm}$.

\subsection{Statistical Analysis}

Statistical analyses were completed using the general linear model procedure of SAS [27]. Standard errors (S.E.M) of means, adjusted by the Tukey method, were estimated by the least square means procedure of SAS [27]. Significance was declared at $p<0.05$ unless otherwise noted.

\section{Results}

\subsection{Morphological Characteristics}

A single strain was isolated from the rumen liquid on basal medium plates containing $1 \mathrm{~g} / \mathrm{L}$ gossypol as the sole carbon source after three days of anaerobic fermentation (Figure 3A), and $49.25 \%$ of gossypol in the medium disappeared. The appearance of colonies on the basal medium plates was rough and dirty white with wrinkly surfaces and irregular shapes. 
The bacteria were positive by Gram-staining (Figure 3B) and confirmed visible rod-shaped bacteria elements by both SEM and TEM observations (Figure 3C,D).

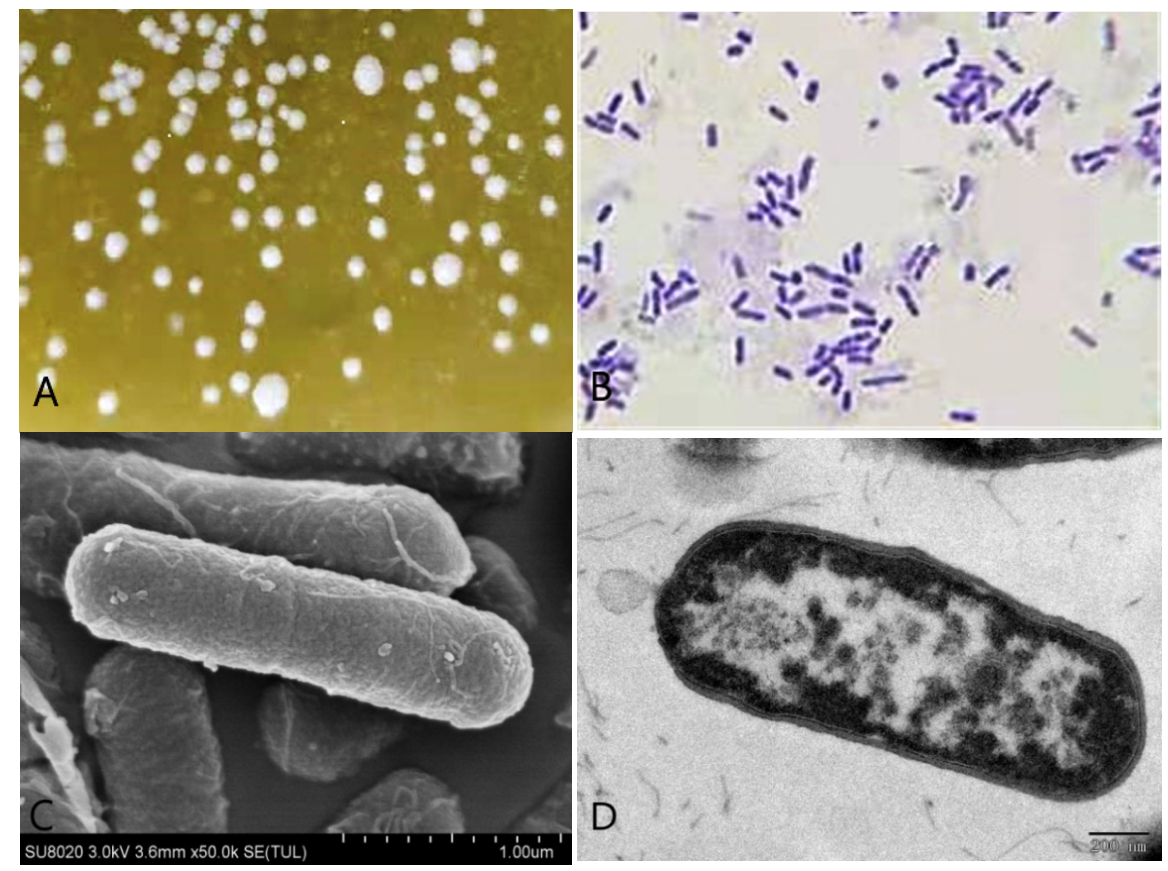

Figure 3. Morphological identification of the L. agilis WWK129 strain. (A) The colony characteristics of this strain; (B) the microstructure characteristics of this strain at 1000 magnification; (C) the scanning electron microscopical observation of this strain; (D) the transmission electron microscopical observation of this strain.

\section{2. $16 S$ rDNA Homology}

The genomic DNA of the isolated strain was successfully extracted and amplified with a bacteria-specific primer pair, which generated an amplicon of about $1.5 \mathrm{~kb}$ and was used for the analysis of a range of bacterial strains. Sequence analysis showed the size of the amplicon was $1446 \mathrm{bp}$. The $16 \mathrm{~S}$ rDNA sequences of isolated strain were aligned using the NCBI-BLAST database, indicating that it is $99.72 \%$ homologous to the sequence of L. agilis strain JCM 1187 (Figure 4). It was the first time that an L. agilis strain that could use gossypol as its sole carbon resource was isolated from the rumen, and it was named L. agilis WWK129 in the present study.

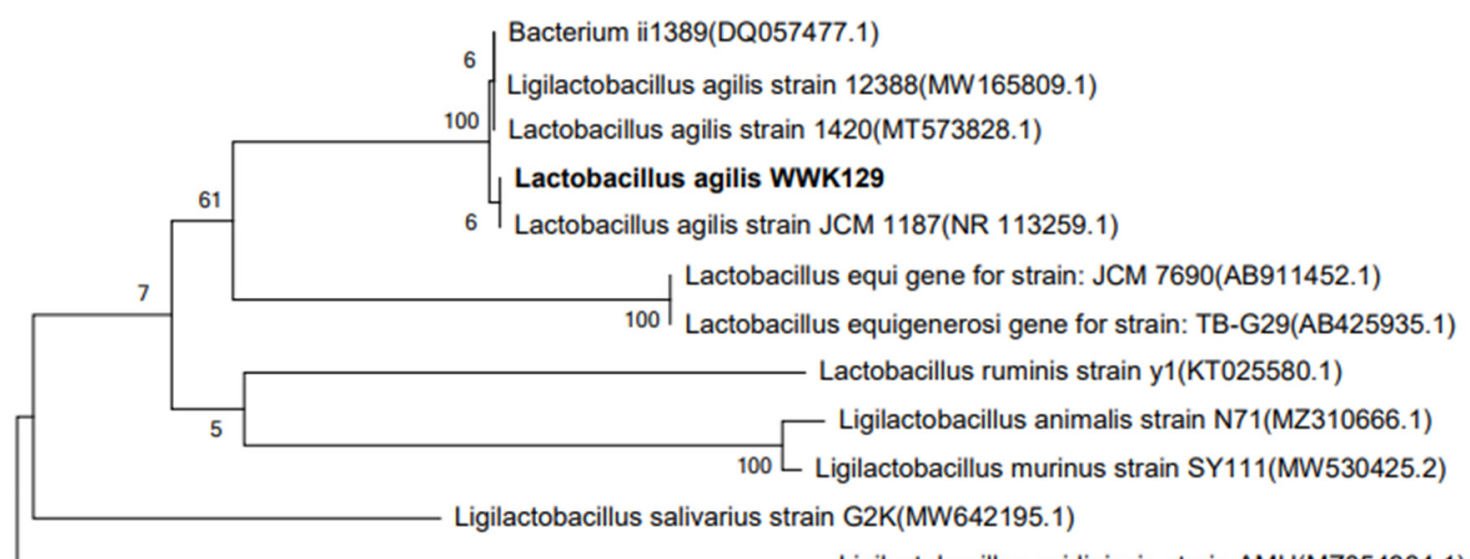

Ligilactobacillus acidipiscis strain AMH(MZ054384.1)

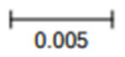

Figure 4. Phylogenetic tree based on 16S rDNA sequence of gossypol-degradation strain L. agilis WWK129. 


\subsection{Growth Study}

There is no obvious difference in bacteria density in different carbon sources in the lag phase. Bacteria in different mediums both exponentially increased after $6 \mathrm{~h}$ of incubation, but the maintenance time of the log phase in gossypol was significantly shorter than it in glucose. There was an obvious decline phase of bacteria in glucose but not in gossypol. The final bacteria density of L. agilis WWK129 in glucose was significantly greater than it in gossypol (Figure 5).

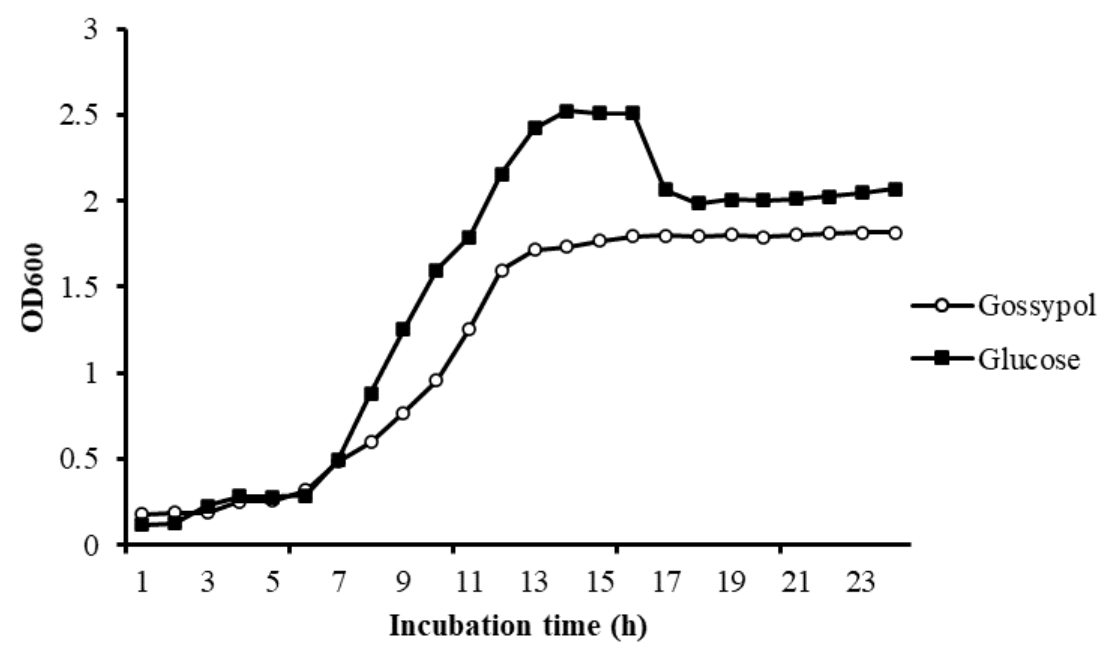

Figure 5. Growth curve of L. agilis WWK129 in carbon source of gossypol and glucose. OD600, optical density of incubated medium at $600 \mathrm{~nm}$.

\subsection{Gossypol Disappearance and Nutrient Shifts of Fermented CSM}

Different culture periods were chosen to evaluate the effect of solid-state fermentation by L. agilis WWK129 strain on the nutritive value of CSM. Compared with the control, the gossypol content of fermented CSM decreased obviously, gossypol degradability increased significantly along with the prolongation of fermentation and it reached over $80 \%$ after five days of anaerobic fermentation (Figure 6). The NDF and ADF contents of CSM decreased significantly after fermentation $(p<0.01)$, while $C P$ and lactic acid content were significantly higher than the control $(p<0.05)$ (Figure 6 and Table 1$)$. It was evident that most amino acids of CSM improved markedly by fermentation of L. agilis WWK129, whereas Aspartic acid, Serine, Glutamic acid, Proline, and Arginine decreased. Among essential amino acids, levels of Phenylalanine increased the most, while among non-essential amino acids, Alanine increased the most.

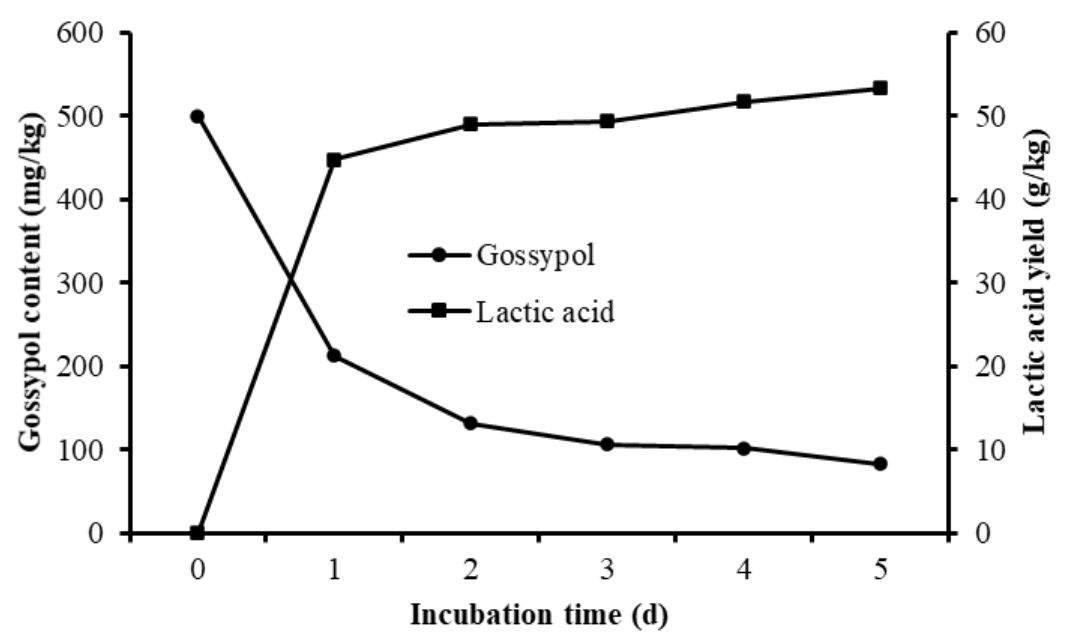

Figure 6. Gossypol content and lactic acid yield of cottonseed meal fermented by L. agilis WWK129. 
Table 1. Nutritive value of cottonseed meal fermented by L. agilis WWK129 (\%, DM).

\begin{tabular}{|c|c|c|c|c|c|c|c|c|c|c|}
\hline \multirow{2}{*}{ Item $^{1}$} & \multicolumn{6}{|c|}{ Fermented CSM at Different Incubation Time } & \multirow{2}{*}{ S.E.M } & \multicolumn{3}{|c|}{$p$ Value } \\
\hline & Con $^{2}$ & 1 Day & 2 Day & 3 Day & 4 Day & 5 Day & & Time & $\mathbf{L}$ & $\mathbf{Q}$ \\
\hline NDF & $16.3^{\mathrm{a}}$ & $15.3^{\mathrm{ab}}$ & $14.9^{\mathrm{ab}}$ & $14.6^{\mathrm{ab}}$ & $13.6^{\mathrm{bc}}$ & $12.7^{\mathrm{c}}$ & 0.46 & $<0.01$ & 0.45 & 0.04 \\
\hline $\mathrm{ADF}$ & $11.3^{\mathrm{a}}$ & $6.8^{\mathrm{b}}$ & $6.5^{c}$ & $6.4^{\mathrm{cd}}$ & $6.3^{\mathrm{de}}$ & $6.1^{\mathrm{e}}$ & 0.05 & $<0.01$ & $<0.01$ & $<0.01$ \\
\hline $\mathrm{CP}$ & $57.6^{b}$ & $60.2^{\mathrm{a}}$ & $60.7^{\mathrm{a}}$ & $60.9^{\mathrm{a}}$ & $61.3^{\mathrm{a}}$ & $61.7^{\mathrm{a}}$ & 0.41 & 0.03 & 0.81 & $<0.01$ \\
\hline Aspartic acid & $4.28^{\mathrm{a}}$ & $4.24^{\mathrm{ab}}$ & $4.24^{\mathrm{ab}}$ & $4.20^{b c}$ & $4.17^{\mathrm{d}}$ & $4.17^{\mathrm{d}}$ & 0.011 & $<0.01$ & 0.29 & $<0.01$ \\
\hline Threonine & $1.29^{c}$ & $1.36^{\mathrm{c}}$ & $1.36^{\mathrm{c}}$ & $1.44^{\mathrm{b}}$ & $1.51^{\mathrm{a}}$ & $1.55^{\mathrm{a}}$ & 0.020 & $<0.01$ & $<0.01$ & 0.01 \\
\hline Serine & $1.77^{\mathrm{a}}$ & $1.64^{\mathrm{b}}$ & $1.65^{b}$ & $1.65^{b}$ & $1.65^{b}$ & $1.67^{b}$ & 0.028 & 0.10 & 0.42 & 0.20 \\
\hline Glutamic acid & $11.36^{\mathrm{a}}$ & $10.74^{\mathrm{ab}}$ & $10.52^{b}$ & $10.42^{b}$ & $10.32^{b}$ & $9.94^{b}$ & 0.222 & 0.04 & 0.50 & 0.01 \\
\hline Proline & $1.46^{\mathrm{a}}$ & $1.28^{\mathrm{b}}$ & $1.27^{\mathrm{b}}$ & $1.19^{b}$ & $1.07^{\mathrm{c}}$ & $0.99^{c}$ & 0.029 & $<0.01$ & 0.11 & $<0.01$ \\
\hline Glycine & 1.87 & 1.90 & 1.91 & 1.92 & 1.93 & 1.99 & 0.034 & 0.36 & 0.31 & 0.13 \\
\hline Alanine & $1.76^{\mathrm{c}}$ & $1.78^{\mathrm{c}}$ & $1.80^{\mathrm{c}}$ & $1.87^{\mathrm{b}}$ & $1.98^{\mathrm{a}}$ & $1.98^{\mathrm{a}}$ & 0.021 & $<0.01$ & $<0.01$ & 0.10 \\
\hline Cysteine & $0.74^{\mathrm{b}}$ & $0.74^{\mathrm{b}}$ & $0.76^{a b}$ & $0.78^{a b}$ & $0.79^{\mathrm{a}}$ & $0.79^{\mathrm{a}}$ & 0.016 & 0.09 & 0.07 & 0.09 \\
\hline Valine & $2.11^{\mathrm{d}}$ & $2.18^{\mathrm{cd}}$ & $2.35^{b c}$ & $2.40^{\mathrm{ab}}$ & $2.48^{\mathrm{ab}}$ & $2.54^{\mathrm{a}}$ & 0.050 & $<0.01$ & 0.01 & $<0.01$ \\
\hline Methionine & $0.56^{c}$ & $0.60^{\mathrm{c}}$ & $0.61^{\mathrm{c}}$ & $0.68^{b}$ & $0.74^{\mathrm{a}}$ & $0.75^{\mathrm{a}}$ & 0.016 & $<0.01$ & $<0.01$ & 0.01 \\
\hline Isoleucine & $1.53^{\mathrm{d}}$ & $1.53^{\mathrm{d}}$ & $1.58^{\mathrm{cd}}$ & $1.64^{b c}$ & $1.67^{\mathrm{ab}}$ & $1.73^{\mathrm{a}}$ & 0.019 & $<0.01$ & 0.01 & $<0.01$ \\
\hline Leucine & $2.71^{\mathrm{d}}$ & $2.79^{c}$ & $2.80^{\mathrm{c}}$ & $2.85^{b}$ & $2.87^{a b}$ & $2.91^{\mathrm{a}}$ & 0.033 & $<0.01$ & $<0.01$ & $<0.01$ \\
\hline Tyrosine & $1.52^{\mathrm{c}}$ & $1.53 \mathrm{bc}$ & $1.56^{\mathrm{abc}}$ & $1.58^{\mathrm{ab}}$ & $1.60^{\mathrm{a}}$ & $1.61^{\mathrm{a}}$ & 0.015 & 0.02 & 0.06 & 0.05 \\
\hline Phenylalanine & $2.53^{\mathrm{d}}$ & $2.75^{c}$ & $2.81^{b c}$ & $2.90^{\mathrm{b}}$ & $3.21^{\mathrm{a}}$ & $3.21^{\mathrm{a}}$ & 0.037 & $<0.01$ & $<0.01$ & $<0.01$ \\
\hline Lysine & $1.90^{b}$ & $1.91^{b}$ & $1.93^{b}$ & $2.18^{a}$ & $2.28^{a}$ & $2.31^{\mathrm{a}}$ & 0.044 & $<0.01$ & $<0.01$ & 0.04 \\
\hline Histidine & 1.27 & 1.25 & 1.27 & 1.28 & 1.27 & 1.27 & 0.016 & 0.59 & 0.19 & 0.35 \\
\hline Arginine & $5.66^{\mathrm{a}}$ & $5.53^{a b}$ & $5.44^{\mathrm{ab}}$ & $5.47^{\mathrm{ab}}$ & $5.21^{b c}$ & $5.09^{\mathrm{c}}$ & 0.089 & 0.03 & 0.40 & 0.12 \\
\hline
\end{tabular}

a,b,c,d,e Values in a line within the same class without a common superscript are significantly different $(p<0.05) .{ }^{1}$ ADF, acid detergent fiber; $\mathrm{CP}$, crude protein; NDF, neutral detergent fiber; L, linear; Q, quadratic. ${ }^{2}$ Con, cottonseed meal inoculated with MRS medium without the isolated strain to prevent the confusion of the effect of medium contents on fermentation results.

\section{Discussion}

\subsection{Identification of L. agilis WWK129}

Many times, rumen microorganisms have been demonstrated to be capable of gossypol biodegradation ability. Chen et al. [28] and Zhang et al. [29] had isolated Bacillus strains from the rumen with high activity of gossypol degradation successively. In the present study, the strain named L. agilis WWK129 which could use gossypol as its sole carbon resource was isolated from the rumen of dairy cows and identified according to morphological and molecular methods. Our previous study had revealed that there was a promoting effect of gossypol on the activity of Firmicutes bacteria [30], and the isolated Lactobacillus belongs to Firmicutes, which was consistent with the result of previous research. Although L. casei and L. plantarum were found to degrade gossypol in previous studies [31,32], there was no report so far about gossypol biodegradation by Lactobacillus strain in the rumen, and this is the first time that a Lactobacillus strain could degrade gossypol isolated from the rumen in the present study.

Lactobacillus species are common constituents of gastrointestinal tracts [33], they have been used as direct-fed probiotics [34] and as silage inoculation [35]. The beneficial effects of Lactobacillus on the production performance of dairy cows included increase in milk yield, improvement of feed efficiency, and increase in daily weight gain [36]. In ruminants, Lactobacillus bacteria are generally only prevalent in young animals before the rumen has properly developed. To date, Lactobacillus bacteria commonly found in the rumen of adult dairy cows included L. ruminis, L. vitulinus, L. acidophilus, L. casei, L. fermentum, L. plantarum, L. buchneri, L. brevis, L. cellobiosus, L. helveticus, and L. salivarius [37]. L. agilis is firstly isolated from municipal sewage in 1981, and it is commonly known as motile Lactobacillus species from sewage and chicken guts $[38,39]$, it was demonstrated that L. agilis played a key role in the degradation of sinigrin, cholesterol, and glucosinolates [40,41]. There was limited knowledge about its function in ruminants, Zhu et al. [42] had isolated several L. agilis from the feces of dairy calves, and found that these bacteria readily degraded long chain inulin. To date, this is the first time found that L. agilis presented the ability of gossypol 
degradation, the successful isolation of L. agilis from the rumen would be helpful for a better understanding of its detoxification mechanism of gossypol in the future.

The method of isolating bacteria from the rumen by screening medium is commonly used for research on the function of rumen bacteria. In the present study, L. agilis WWK129 statin was cultivated in a basal medium using gossypol as the only carbon source, and about $50 \%$ of gossypol in basal medium plates disappeared after three days of anaerobic fermentation, which demonstrated that gossypol could provide the carbon source for its growth by biodegradation rather than transformation. The exponential phase of growth curve is a stage in which microbial cells are divides at the maximal rate and the nature of the medium is being used as quickly as possible. According to the growth curve of L. agilis WWK129 in different carbon resources, the maintained time and slope of exponential phase in gossypol was smaller than glucose, which noted that L. agilis WWK129 grow faster in glucose instead of gossypol. It was assumed that a variety of environmental conditions cause the death of microorganisms, such as the depletion of essential nutrients in the decline phase. The optical density of the medium containing glucose decreased significantly after $16 \mathrm{~h}$ of incubation, this was mainly due to the decrease of nutrient composition of medium and the increase of cell metabolites which inhibited the growth of incubated bacteria. There was no decline phase in medium contained gossypol after $24 \mathrm{~h}$ of incubation and the final density of L. agilis WWK129 in stationary phase was greater in medium contained glucose, which revealed that the biodegradation and transformation rate of gossypol was relatively slow and difficult, and the utilization efficiency of gossypol was lower than glucose.

\subsection{Effect of L. agilis WWK129 Fermentation on the Nutritional Value of CSM}

In the present study, fiber content of control group inoculated with MRS medium without $L$ agilis WWK129 were consistent with the original CSM sample, while CP content was significant higher than original state, this could be due to the peptone in MRS medium which improved the $\mathrm{CP}$ level of control group. According to the results of Chen et al. [28] and Zhang et al. [29], Bacillus strains isolated from the rumen applied in optimum fermentation conditions, the gossypol content in solid-state fermented CSM decreased by $80 \%$, relative to the control. In the current study, it was found that over than $80 \%$ gossypol in CSM could be degraded by L. agilis WWK129 in solid-state fermentation after five days, which was relatively greater than previous research, it could be due to the different fermentation conditions, CSM variety, and gossypol biodegradation ability of stains. The disappearance of gossypol could be due to the biodegradation of microbial enzymes secreted by L. agilis WWK129 and gossypol, its metabolites could also be used by L. agilis WWK129 as a carbon resource as well. Wu [43] investigated the effect of solid-state fermentation by three types of L. acidophilus on the nutritional value of CSM and found that lactic acid and essential amino acids content of fermented CSM were greater than the control, which was consistent with the results of the present study. The improvement of $\mathrm{CP}$ and amino acids content in fermented CSM was mainly due to the growth of microflora, as well as the increase of cellular protein and microbial enzymes secreted by L. agilis WWK129, which could promote the nutritive value and utilization efficiency of protein in CSM. The fiber content of fermented CSM was significantly lower than that of CSM without inoculum, it was noted that L. agilis WWK129 could be helpful for the degradation of fiber, and the reduction of fiber could provide carbon resources for the growth of L. agilis WWK129. Lactic acid is a key end-product of Lactobacillus fermentation, and lactic acid content persistently increased along with the incubation reflected that the fermentation conditions in the present study were suitable for the growth of L. agilis WWK129.

Solid-state microbial fermentation is an important method used for gossypol detoxification in the cotton by-products process, and Candida tropicalis and Lactobacillus plantarum were commonly used in the fermentation of CSM feed sources in previous research. Zhang et al. [44] found that gossypol degradability in CSM fermented by C. tropicalis ZD-3 reached $94.6 \%$ after $48 \mathrm{~h}, \mathrm{CP}$ content increased by about $11 \%$ compared with the control, total amino 
acids, and essential amino acids content of fermented CSM increased by $27 \%$ and $29 \%$, respectively. Khalaf and Meleigy [15] investigated the effect of fungi on gossypol content of CSM by solid-state fermentation and found that C. tropicalis could degrade $86.18 \%$ gossypol after $72 \mathrm{~h}$ of incubation at $30^{\circ} \mathrm{C}$. Hong [45] found that gossypol degradability in CSM with $5 \%$ inoculum of L. plantarum reached $40 \%$ after $60 \mathrm{~h}$ solid-state fermentation at $30^{\circ} \mathrm{C}$. There is no report about feed resource fermented by L. agilis in previous, the results of the current study have verified the feasibility of L. agilis used in solid-state fermentation of CSM and provided more bacteria selection for the microbial fermentation of cotton by-products in the future.

Lactobacillus strains were approved for use as probiotics for both humans and animals [46,47], and the colonization of Lactobacillus strains in the gut epithelium could reduce the risk of pathogenic bacterial infection by the production of lactic acid and other metabolites [48]. Lactic acid in fermented CSM feed sources can increase acidity, inhibit the growth of spoilage bacteria and prevent the mildew of feed. In addition, all of this research demonstrated that the fermentation of Lactobacillus strain can significantly increase the content of essential amino acids and improve aminol acids balance. Consequently, the use of L. agilis WWK129 in CSM fermentation can not only reduce the toxicity of gossypol and promote nutritive value, but also be conducive to the health of animals.

\section{Conclusions}

Collectively, the present study noted that L. agilis WWK129, firstly isolated from the rumen contents, presented the great potential for gossypol biodegradation. Gossypol disappearance rate in cottonseed meal reached up to $80 \%$ after 5 days of anaerobic fermentation by the isolated strain, meanwhile, neutral detergent fiber and acid detergent fiber content decreased by about $4 \%$ and $5 \%$, respectively, crude protein content increased by about $4 \%$ and most essential amino acids content improved significantly, suggesting that the L. agilis WWK129 has promising application prospect in gossypol detoxification and microbial fermentation of cottonseed meal, and it could provide a basis for further analysis of gossypol biodegradation in the rumen.

Author Contributions: Conceptualization, W.-K.W. and Y.-L.W.; methodology, W.-K.W.; software, W.-J.L.; validation, Q.-C.W.; formal analysis, W.-K.W.; investigation, Y.-L.W.; resources, W.-J.L. and Q.-C.W.; data curation, W.-K.W.; writing-original draft preparation, W.-K.W.; writing-review and editing, S.-L.L. and H.-J.Y.; visualization, H.-J.Y.; supervision, H.-J.Y.; project administration, H.-J.Y.; funding acquisition, S.-L.L. All authors have read and agreed to the published version of the manuscript.

Funding: This research was funded by the Key Research and Development Project of Ningxia Hui Autonomous Region, grant number 2018BBF33006.

Institutional Review Board Statement: The study was conducted according to the guidelines of the Declaration of Helsinki, and approved by the Institutional Review Board of Institutional Animal Care Committee of China Agricultural University (protocol code CAU20171014-1 and date of approval 25 September 2020).

Data Availability Statement: Data from the study are available in NCBI-GenBank under accession number MZ 779227.

Conflicts of Interest: The authors declare no conflict of interest.

\section{References}

1. Santos, J.E.P.; Villaseňor, M.; Depeters, E.J.; Robinson, P.H.; Baldwin, B.C., Jr. Type of cottonseed and level of gossypol in diets of lactating dairy cows: Effects on lactation performance and plasma gossypol. J. Dairy Sci. 2002, 85, 1491-1501. [CrossRef]

2. Krempl, C.; Heidel-Fischer, H.M.; Jiménez-Alemán, G.H.; Reichelt, M.; Menezes, R.C.; Boland, W.; Vogel, H.; Heckel, D.G.; Joußen, N. Gossypol toxicity and detoxification in Helicoverpa armigera and Heliothis virescens. Insect Biochem. Mol. Biol. 2016, 78, 69-77. [CrossRef] [PubMed]

3. Robinson, P.H.; Getachew, G.; De Peters, E.J.; Calhoun, M.C. Influence of variety and storage for up to 22 days on nutrient composition and gossypol level of Pima cottonseed (Gossypium spp.). Anim. Feed. Sci. Technol. 2001, 91, 149-156. [CrossRef] 
4. Velasquez-Pereira, J.; Arechiga, C.F.; McDowell, L.R.; Hansen, P.J.; Chenoweth, P.J.; Calhoun, M.C.; Risco, C.A.; Batra, T.R.; Williams, S.N.; Wilkinson, N.S. Effects of gossypol from cottonseed meal and dietary vitamin E on the reproductive characteristics of superovulated beef heifers. J. Anim. Sci. 2002, 80, 2485-2492. [CrossRef] [PubMed]

5. Santos, J.E.P.; Villaseñor, M.; Robinson, P.H.; Depeters, E.J.; Holmberg, C.A. Type of Cottonseed and Level of Gossypol in Diets of Lactating Dairy Cows: Plasma Gossypol, Health, and Reproductive Performance. J. Dairy Sci. 2003, 86, 892-905. [CrossRef]

6. Wang, X.; Howell, C.P.; Chen, F.; Yin, J.J.; Jiang, Y.M. Gossypol-A polyphenolic compound from cotton plant. Adv. Food Nutr. Res. 2009, 58, 215-263.

7. Reiser, R.; Fu, H.C. The Mechanism of Gossypol Detoxification by Ruminant Animals. J. Nutr. 1962, 76, 215-218. [CrossRef] [PubMed]

8. Feng, Y.; Wang, Y. The nutrition value and metabolism of cottonseed in ruminants. Feed. Res. 2011, 4, 13-16.

9. Rahma, E.H.; Rao, M.S.N. Gossypol Removal and Functional Properties of Protein Produced by Extraction of Glanded Cottonseed with Different Solvents. J. Food Sci. 1984, 49, 1057-1060. [CrossRef]

10. Tabatabai, F.; Golian, A.; Salarmoeini, M. Determination and detoxification methods of cottonseed meal gossypol for broiler chicken rations. Agric. Sci. Technol. 2002, 16, 3-15.

11. Nagalakshmi, D.; Sastry, V.R.B.; Pawde, A. Rumen fermentation patterns and nutrient digestion in lambs fed cottonseed meal supplemental diets. Anim. Feed. Sci. Technol. 2003, 103, 1-14. [CrossRef]

12. Wu, X.Y.; Chen, J.X. The utilization of microbes to break down FG in cottonseed meal. Sci. Agric. Sin. 1989, 22, 82-86.

13. Weng, X.-Y.; Sun, J.-Y. Biodegradation of free gossypol by a new strain of Candida tropicalis under solid state fermentation: Effects of fermentation parameters. Process. Biochem. 2006, 41, 1663-1668. [CrossRef]

14. Weng, X.-Y.; Sun, J.-Y. Kinetics of biodegradation of free gossypol by Candida tropicalis in solid-state fermentation. Biochem. Eng. J. 2006, 32, 226-232. [CrossRef]

15. Khalaf, M.A.; Meleigy, S.A. Reduction of free gossypol levels in cottonseed meal by microbial treatment. Int. J. Agric. Biol. 2008, 10, 185-190.

16. Yang, X.; Sun, J.-Y.; Guo, J.-L.; Weng, X.-Y. Identification and proteomic analysis of a novel gossypol-degrading fungal strain. J. Sci. Food Agric. 2011, 92, 943-951. [CrossRef] [PubMed]

17. DeRuiter, J.; Jacyno, J.M.; Davis, R.A.; Cutler, H.G. Studies on Aldose Reductase Inhibitors from Fungi. I. Citrinin and Related Benzopyran Derivatives. J. Enzym. Inhib. 1992, 6, 201-210. [CrossRef]

18. De Mann, J.C.; Rogosa, M.; Sharpe, M.E. A medium for cultivation of Lactobacill. J. Appl. Microb. 1969, 23, $130-135$.

19. Perfumo, A.; Elsaesser, A.; Littmann, S.; Foster, R.A.; Kuypers, M.M.; Cockell, C.S.; Kminek, G. Epifluorescence, SEM, TEM and nanoSIMS image analysis of the cold phenotype of Clostridium psychrophilum at subzero temperatures. FEMS Microbiol. Ecol. 2014, 90, 869-882. [CrossRef]

20. Zhang, Y.; Luan, H.; Wei, Z.; Hao, Z.; Xi, R.; Liao, X. Exploiting of honey-associated Bacillus strains as plant-growth promoting bacteria for enhancing barley growth in rare earth tailings. Ann. Microbiol. 2015, 66, 559-568. [CrossRef]

21. Saitou, N.; Nei, M. The neighbor-joining method: A new method for reconstructing phylogenetic trees. Mol. Biol. Evol. 1987, 4, 406-425. [CrossRef] [PubMed]

22. Tamura, K.; Dudley, J.; Nei, M.; Kumar, S. Mega 4: Molecular evolutionary gnentics analysis (MEGA) software version 4.0. Mol. Biol. Evol. 2007, 24, 1596-1599. [CrossRef] [PubMed]

23. AOAC. Official Methods of Analysis of AOAC International, 18th ed.; Association of Official Analytical Chemists International: Gaithersburg, MD, USA, 2005.

24. Van Soest, P.J.; Robertson, J.B.; Lewis, B.A. Methods for dietary fiber, neutral fiber, and nonstarch polysaccharides in relation to animal nutrition. J. Dairy Sci. 1991, 74, 3583-3597. [CrossRef]

25. Cira, L.A.; Huerta, S.; Hall, G.M.; Shirai, K. Pilot scale lactic acid fermentation of shrimp wastes for chitin recovery. Process. Biochem. 2002, 37, 1359-1366. [CrossRef]

26. Wang, W.-K.; Wang, Y.-L.; Li, W.-J.; Wu, Q.-C.; Li, S.-L.; Yang, H.-J. Gossypol Exhibited Higher Detrimental Effect on Ruminal Fermentation Characteristics of Low-Forage in Comparison with High-Forage Mixed Feeds. Toxics 2021, 9, 51. [CrossRef]

27. SAS. Statistical Analytical System (SAS) Users Guides: Statistics; Version 8.2; Statistica Analysis Institute: Cary, NC, USA, 1999.

28. Chen, L.; Zh, Y.; Ch, X.; Ch, M.; Meng, X.; Cai, H. Gossypol Degradation Strain Coming from Ruminant Rumens and Application Thereof. CN 104328063A, 4 February 2015.

29. Zhang, Y.; Zhang, Z.; Dai, L.; Liu, Y.; Cheng, M.; Chen, L. Isolation and characterization of a novel gossypol-degrading bac-teriabacillus subtilis strain rumen bacillus subtilis. Asian Austral. J. Anim. 2018, 31, 63-70. [CrossRef] [PubMed]

30. Wang, W.-K.; Wang, Y.-L.; Li, W.-J.; Wu, Q.-C.; Yang, K.-L.; Li, S.-L.; Yang, H.-J. In situ rumen degradation characteristics and bacterial colonization of whole cottonseed, cottonseed hull and cottonseed meal with different gossypol content. AMB Express 2021, 11, 91. [CrossRef] [PubMed]

31. Tang, H.W.; Wu, Y.F.; Yao, X.H.; Wang, X. Method for Removing Free Gossypol from Cotton Dregs by Biological Fermentation Method. CN102138632B, 24 July 2013.

32. Chen, W.; Tian, F.W.; Zhai, Q.X.; Sun, Y.Y.; Zhao, J.X.; Wang, G.; Zhang, Q.X.; Liu, X.M.; Zhang, B.X.; Zhang, H. Lactobacillus Plantarum Capable of Degrading Gossypol and Application of Lactobacillus Plantarum. CN105255793A, 20 January 2016.

33. Heeney, D.D.; Gareau, M.G.; Marco, M.L. Intestinal Lactobacillus in health and disease, a driver or just along for the ride? Curr. Opin. Biotechnol. 2018, 49, 140-147. [CrossRef] [PubMed] 
34. Lebeer, S.; Bron, P.A.; Marco, M.L.; Pijkeren, J.P.V.; Motherway, M.O.C.; Hill, C.; Pot, B.; Roos, S.; Klaenhammer, T. Identification of probiotic effector molecules: Present state and future perspectives. Curr. Opin. Biotechnol. 2018, 49, 217-223. [CrossRef]

35. Muck, R.E.; Nadeau, E.M.G.; McAllister, T.A.; Contreras-Govea, F.E.; Santos, M.C.; Kung, L., Jr. Silage review: Recent advances and future uses of silage additives. J. Dairy Sci. 2018, 101, 3980-4000. [CrossRef]

36. Doyle, N.; Mbandlwa, P.; Kelly, W.J.; Attwood, G.; Li, Y.; Ross, R.P.; Stanton, C.; Leahy, S. Use of Lactic Acid Bacteria to Re-duce Methane Production in Ruminants, a Critical Review. Front. Microbiol. 2019, 10, 2207. [CrossRef]

37. Feng, Y.L. Ruminant Nutrition; Science Press: Beijing, China, 2004; pp. 10-11.

38. Stephenson, D.P.; Moore, R.J.; Allison, G.E. Transformation of, and Heterologous Protein Expression in, Lactobacillus agilis and Lactobacillus vaginalis Isolates from the Chicken Gastrointestinal Tract. Appl. Environ. Microbiol. 2011, 77, 220-228. [CrossRef]

39. Kajikawa, A.; Midorikawa, E.; Masuda, K.; Kondo, K.; Irisawa, T.; Igimi, S.; Okada, S. Characterization of flagellins isolated from a highly motile strain of Lactobacillus agilis. BMC Microbiol. 2016, 16, 1-8. [CrossRef]

40. Palop, M.L.; Smiths, J.P.; Brink, B.T. Degradation of sinigrin by Lactobacillus agilis strain R16. Int. J. Food Microbiol. 1995, 26, 219-229. [CrossRef]

41. Luangin, V. Influence of Human Gut Microbiota on the Metabolic Fate of Glucosinolates; Imperial College London: London, UK, 2013.

42. Zhu, Y.; Liu, J.; Lopez, J.M.; Mills, D.A. Inulin Fermentation by Lactobacilli and Bifidobacteria from Dairy Calves. Appl. Environ. Microbiol. 2020, 87, e01738-20. [CrossRef] [PubMed]

43. Wu, Y.Y. A Study on Screening and Breeding of High-Yield Lactic Acid Bacteria and the Nutritional Characteristics of Fermented Cottonseed Meal; Shihezi University: Shihezi, China, 2013.

44. Zhang, W.-J.; Xu, Z.-R.; Zhao, S.-H.; Sun, J.-Y.; Yang, X. Development of a microbial fermentation process for detoxification of gossypol in cottonseed meal. Anim. Feed. Sci. Technol. 2007, 135, 176-186. [CrossRef]

45. Hong, Z. Microbial Solid Fermentation to Reduce Free Gossypol Content in the Cottonseed Meal; Wuhan Polytechnic University: Wuhan, China, 2016.

46. Peran, L.; Sierra, S.; Comalada, M.; Lara-Villoslada, F.; Bailón, E.; Nieto, A.; Concha, Á.; Olivares, M.; Zarzuelo, A.; Xaus, J.; et al. A comparative study of the preventative effects exerted by two probiotics, Lactobacillus reuteri and Lactobacillus fermentum, in the trinitrobenzene sulfonic acid model of rat colitis. Br. J. Nutr. 2007, 97, 96-103. [CrossRef]

47. Śliżewska, K.; Chlebicz-Wójcik, A.; Nowak, A. Probiotic Properties of New Lactobacillus Strains Intended to Be Used as Feed Additives for Monogastric Animals. Probiotics Antimicrob. Proteins 2021, 13, 146-162. [CrossRef]

48. Slover, C.M.; Danziger, L. Lactobacillus: A Review. Clin. Microbiol. Newsl. 2008, 30, 23-27. [CrossRef] 